Journal of Epidemiology and Public Health (2019), 4(4): 320-327

https://doi.org/10.26911/jepublichealth.2019.04.04.07

\title{
Determinants of Quality of Life among Patient with Knee Osteoarthritis
}

\author{
Wika Yuniarwati'), Achmad Arman Subijanto²), Hanung Prasetyo3) \\ 1)Masters Program in Public Health, Universitas Sebelas Maret \\ 2)Faculty of Medicine, Universitas Sebelas Maret \\ 3)Department of Acupuncture, School of Health Polytechnics, Ministry of Health Surakarta
}

\begin{abstract}
Background: Osteoarthritis (OA) ranks second after cardiovascular disease as the cause of physical disability. Nearly 25\% of individuals aged 55 years or over have complaints of knee pain and some have proven osteoarthritis. Elderly people with OA suffer from depression, reduced quality of life and economic difficulties. In assessing the quality of life of OA patients can help identify the health care needs of all patients. This study aimed to determine factors affecting quality of life in knee OA patients.
\end{abstract}

Subjects and Method: This was analytic observational study with a cross sectional design. The study was carried out at Dr. Moewardi and UNS Hospital, Surakarta, Central Java. A sample of 180 OA knee patients was selected by consecutive sampling. The dependent variable was quality of life. The independent variables were sex, occupation, body mass index, duration of illness, and pain location. The data were collected by questionnaire and analyzed by a multiple logistic regression.

Results: Quality of life of OA knee patient decreased with female $(b=-1.11 ; 95 \% \mathrm{CI}=\mathbf{- 2 . 3 2}$ to 0.08 ; $\mathrm{p}=0.069)$, overweight/ obesity $(\mathrm{b}=-1.64 ; 95 \% \mathrm{CI}=-2.35$ to $-0.93 ; \mathrm{p}<0.001)$, duration of chronic illness $(b=-0.80 ; 95 \% C I=-1.51$ to $-0.91 ; p=0.027)$, and bilateral pain $(b=-0.74 ; 95 \% C I=-1.42$ to $0.05 ; \mathrm{p}=0.034)$.

Conclusion: Quality of life of OA knee patient decreases with female, overweight/ obesity, duration of chronic illness, and bilateral pain.

Keywords: quality of life, kne eosteoarthritis, logistic regression

\section{Correspondence:}

Wika Yuniarwati. Masters Program in Public Health, Sebelas Maret University, Jl. Ir. Sutami 36A, Surakarta, Central Java. Email: wickafisio@gmail.com. Mobile: + 62812279-33068.

\section{BACKGROUND}

Data from the Statistics Indonesia (BPS) reports on the projected population of Indonesia in 2010-2035 showing an increase in life expectancy from 69.8 years in 2010 to 70.9 years in 2017 and is expected to increase to 72.4 in the coming 2035 (BPS, 2017). However, this increase in life expectancy can result in epidemiological changes in the health sector due to increasing numbers of morbidity due to degenerative diseases $(\mathrm{MOH}, 2018)$. One type of degenerative disease is osteoarthritis.

Osteoarthritis (OA) ranks second after cardiovascular disease as the cause of phy- sical disability (such as walking and climbing stairs). Overall, about $10-15 \%$ of adults over 60 years suffer from OA (Maharani, 2007). Osteoarthritis occurs because of a dynamic process characterized by progressive loss of joint cartilage associated with remodeling and subcondral bone sclerosis. Knee OA is an important subgroup of degenerative joint disease which is a major cause of functional limitations when walking or when performing other activities that involve the lower limbs (Lowry et al., 2017).

Kusumaningtyaset al (2019) in his study on risk factors for knee OA in Dr. Moewardi Surakarta, mentioned that of $5^{\circ}$ 
knee OA patients, $98 \%$ were aged $\geq 40$ years and the remaining $2 \%$ aged $<40$ years consisted of $52 \%$ men and $48 \%$ women. Older people with OA experience depression, reduced quality of life, and economic difficulties. OA has a significant impact on declining quality of life (Zakaria et al., 2009). Increasing life expectancy and quality of life are very important topics to be studied. The main challenge in the 2oth century is to increase life expectancy. Then, the main challenge in the 21st century is to live with high quality (Ermawati et al., 2018). There are various factors that can affect the quality of life of knee OA patients, namely sociodemographic factors and clinical data such as age, sex, marital status, residence status, education level, household income, height, weight, and body mass index are also related to quality health-related life in knee OA patients (Sazlina et al., 2012). Health-related quality of life focuses on the impact of health on one's ability to live satisfying lives (CDC, 2018).

Several studies have been conducted in Indonesia regarding the quality of life in patients with knee osteoarthritis. Picture of quality of life and anxiety level of knee osteoarthritis patients in medical rehabilitation installation Dr. Kariadi Semarang showed the results of the SF-36 questionnaire from 24 patients with knee osteoarthritis who had a poor quality of life (Hafiz and Tanti, 2015). Other related study regarding the evaluation of the quality of life of osteoarthritis sufferers in the outpatient hospital Dr. Sardjito found that there was a significant effect between the variables of age, occupation, and pain intensity on quality of life. While, sex, comorbidities, and type of therapy did not affect the quality of life of osteoarthritis sufferers (Ismail et al., 2013).

Researchers have not found any study about the quality of life in knee osteo- arthritis patients in the Surakarta residency, therefore the purpose of this study is to determine the factors that affect the quality of life of knee osteoartritits (OA).

\section{SUBJECTS AND METHOD \\ 1. Study Design \\ This was an analytic observational study with a cross sectional design. The study was conducted at Dr. Moewardi Hospital and UNS Hospital, Surakarta, Central Java, from May to July 2019.}

\section{Population and Sample}

The study population was all knee osteoarthritis (OA) patients who visited medical rehab installations from May to July. The sample in this study were knee OA patients who met the inclusion criteria including patients with a diagnosis of knee OA, willing to sign informed consent. Exclusion criteria included illiteracy and deafness, as well as knee OA patients who had undergone knee surgery. The numbers of samples in this study were 180 subjects obtained from sampling using consecutive sampling that was samples that came and met the selection criteria were taken until the required number of samples were met.

\section{Study Variables}

The dependent variable was quality of life. The independent variables were sex, occupation, body mass index, duration of illness, and location of pain.

\section{Operational Definition of Variables}

Sex was the identity of the sample based on physical and biological conditions from birth expressed in the sex of male or female. The data were collected by questionnaire. The measurement scale was categorical.

Occupation was something someone did to make a living. The data were collected by questionnaire. The measurement scale was categorical. 
Body mass index was a measurement to find out a person's nutritional status related to underweight or overweight. Body weight was measured by weight scale. Body height was measured by microtois. The measurement scale was continuous.

The duration of illness was the period from the diagnosis of the disease to the time the study data was collected. The data were collected by questionnaire. The measurement scale was continous.

The pain location was the place of disease, in the case of knee OA can occur on one side (unilateral) or two sides of the knee (bilateral). The data were collected by questionnaire. The measurement scale was categorical.

Quality of life was steps related to evaluating health status, values and satisfaction levels based on health conditions, which were assessed by the individual concerned. The data were collected by SF-36 questionnaire. The measurement scale was continous.

\section{Data Analysis}

Univariate analysis explains the general description of study data including sex,

Table 1. Univariate Analysis

\begin{tabular}{lcc}
\hline \multicolumn{1}{c}{ Variable } & $\mathbf{n}$ & $\mathbf{\%}$ \\
\hline Sex & & \\
Male & 75 & 41.7 \\
Female & 105 & 58.3 \\
Occupation & 88 & 48.9 \\
Employed & 92 & 51.1 \\
Unemployed & & 38.9 \\
Body Mass Index & 70 & 61.1 \\
Normal & 110 & 41.7 \\
Overweight/ obese & & 58.3 \\
Length of Illness & 75 & 45.0 \\
Acute & 105 & 55.0 \\
Location of Pain & & 43.3 \\
Unilateral & 81 & 56.7 \\
Bilateral & 99 & \\
Quality of life & & \\
Good & 78 & \\
Poor & 102 & \\
\hline
\end{tabular}

occupation, body mass index, duration of illness, location of pain, and quality of life related to health.

Bivariate analysis explains the effect of each independent variable (sex, occupation, body mass index, duration of illness, and location of pain) on the dependent variable (quality of life related to health) was measured by Chi-square test.

Multivariate analysis explained the effect of sex, occupation, body mass index, illnessduration, and location of pain on health-related quality of life which was analyzed by a multiple logistic regression model run on Stata 13.

\section{Research Ethics}

The research ethics includes the promotion sheet, anonymity, confidentiality, and research ethics. Research ethics was obtained from Research Ethics Committee at Dr. Moewardi Hospital, Surakarta, Central Java, with number 445/III/HREC/2019.

\begin{tabular}{l}
\hline RESULTS \\
\hline 1. Univariate Analysis \\
Tabel 1 shows the results of univariate \\
analysis.
\end{tabular}


The samples of the study which were male were $41.7 \%$ and female were $58.3 \%$. The study sample which had skilled occupation was $48.9 \%$ and unskilled occupation was $51.1 \%$. The study sample which had an excessive body mass index was $61.1 \%$ and not excessive was $38.9 \%$.

The study sample which has acute illness was $41.7 \%$ and chronic was $58.3 \%$. The study sample experienced unilateral knee OA pain (one side of the knee) by $45 \%$ and bilateral (two sides of the knee) by $55 \%$. The study sample that has a poor quality of life was $56.7 \%$ and good quality of life as much as $43.4 \%$.

\section{Bivariate Analysis}

Table 2.shows the results of the bivariate analysis, the effect between each indepen-

Table 2.Bivariate Analysis

\begin{tabular}{|c|c|c|c|c|c|c|}
\hline \multirow{2}{*}{ Independent variables } & \multicolumn{2}{|c|}{ Poor } & \multicolumn{2}{|c|}{ Good } & \multirow{2}{*}{$\mathbf{O R}$} & \multirow[b]{2}{*}{$\mathbf{p}$} \\
\hline & $\mathbf{n}$ & $\%$ & $\mathbf{n}$ & $\%$ & & \\
\hline \multicolumn{7}{|l|}{ Sex } \\
\hline Male & 34 & $45 \cdot 3$ & 41 & $54 \cdot 7$ & & \\
\hline Female & 68 & 64.8 & 37 & 35.2 & & \\
\hline \multicolumn{7}{|l|}{ Occupation } \\
\hline Skilled occupation & 56 & 63.6 & 32 & 36.4 & 1.75 & 0.065 \\
\hline Unskilled occupation & 46 & 50.0 & 46 & 50.0 & & \\
\hline \multicolumn{7}{|l|}{ Body Mass Index } \\
\hline Excess & 26 & 37.1 & 44 & 62.9 & 0.26 & $<0.001$ \\
\hline Not excess & 76 & 69.1 & 34 & 30.9 & & \\
\hline \multicolumn{7}{|l|}{ Duration of Illness } \\
\hline Acute & 49 & $65 \cdot 3$ & 26 & $34 \cdot 7$ & 1.85 & 0.047 \\
\hline Chronic & 53 & 50.5 & 52 & 49.5 & & \\
\hline \multicolumn{7}{|l|}{ Pain location } \\
\hline Unilateral & 50 & 50.5 & 49 & 49.5 & 0.57 & 0.065 \\
\hline Bilateral & 52 & 64.2 & 29 & 35.8 & & \\
\hline
\end{tabular}

There was an association between BMI and quality of life. Overweight/ obese patients were likely to have a poor quality of life 0.26 times than patients with normal BMI (OR 0.26; p<0.001).

There was an association between the length of illness and the quality of life. Knee OA patients who had chronic disease were dent variable (sex, occupation, body mass index, duration of illness, and location of pain) and the dependent variable (quality of life).

The table shows that there was an association between sex and quality of life. Osteoarthritis (OA) knee patients who have a female sex are likely to have a poor quality of life 0.45 times compared to male sex $(\mathrm{OR}=0.45 ; \mathrm{p} 0.010)$.

There was no association between occupation and quality of life. Knee Osteoarthritis (OA) who had fine jobs are likely to have a poor quality of life 1.75 times compared to those who have menial occupation $(\mathrm{OR}=1.75 ; \mathrm{p}=0.065)$. 
those with unilateral knee $\mathrm{OA}$ pain $(\mathrm{OR}=$ $0.57 ; \mathrm{p}=0.065$ ).

\section{Multivariate Analysis}

Table 3 shows the results of multivariate analysis, the effect of sex, occupation, body mass index, duration of disease, and location of pain on the quality of life of knee OA patients using a multiple logistic regression model.

There was an association between sex and quality of life of knee OA patients.
Female knee OA patients have logodd for good quality of life 1.11 lower than male sex $(\mathrm{b}=-1.11 ; 95 \% \mathrm{CI}=-2.32$ to $0.08 ; \mathrm{p}=$ 0.069). There was no association between occupation and quality of life of knee OA patients. Knee OA patients with hard occupation have a logodd for good quality of life 0.07 higher than knee OA patients with fine occupation $(\mathrm{b}=0.07$; $95 \% \mathrm{CI}=-1.10$ to 1.25 ; $\mathrm{p}=0.900)$.

Table 3. Multiple logistic regression analysis

\begin{tabular}{lcccc}
\hline \multirow{2}{*}{ Independent variable } & \multirow{2}{*}{$\mathbf{b}$} & \multicolumn{2}{c}{ 95\% CI } & p \\
\cline { 3 - 4 } & & Lower limit & Upper limit & \\
\hline Sex (female) & -1.11 & -2.32 & 008 & 0.069 \\
Occupation (unemployed) & 0.07 & -1.10 & 1.25 & 0.900 \\
BMI (>25 kg/m²) & -1.64 & -2.35 & -0.93 & $<0.001$ \\
Length of illness ( $\geq 6$ months) & -0.80 & -0.80 & -1.51 & 0.027 \\
Pain location (bilateral) & -0.74 & -1.42 & -0.05 & 0.034 \\
N Observation $=180$ & & & & \\
Log Likelihood $=-104.03$ & & & & \\
\hline
\end{tabular}

There was an association between BMI and quality of life of OA knee patients. OA knee patients with excessive body mass index or obesity have a logodd for good quality of life 1.64 lower than non-excessive body mass index $(b=-1.64 ; 95 \% \mathrm{CI}=-2.35$ to $-0.93 ; \mathrm{p}<0.001)$. There is an association between duration of illness and quality of life of OA knee patients. Knee OA patients with chronic disease duration had a good quality of life 0.80 lower than the duration of acute illness $(b=-0.80,95 \% \mathrm{CI}=-1.51$ to $0.91, p=0.027)$. There was an association between the location of knee OA pain and the quality of life. OA patients with bilateral pain locations had a good quality of life 0.74 lower than unilateral pain $(b=-0.74$, $95 \% \mathrm{CI}=-1.42$ to $-0.05, \mathrm{p}=0.034$ ).

\section{DISCUSSION}

\section{The effect of sex on the quality of life of knee $\mathrm{OA}$ patients}

The analysis shows that there is an association between sex and quality of life of knee OA patients. The negative association between sex and quality of life means that knee OA patients with female sex have a good quality of life $\mathbf{1 . 1 1}$ lower than male knee OA patients. The results of this study are in line with a study by Zakaria et al. (2009) regarding health-related quality of life in knee OA patients who visited two health service clinics in Malaysia which showed better male results in assessments in almost all domains of quality of life especially the domain of physical roles (limited activity due to physical health problems).

Female respondents who experienced knee OA were found to have lower values than male respondents with knee OA, in almost all dimensions of quality of life. This happens because the prevalence of women affected by knee OA is greater, in addition to that women are more likely to experience joint stiffness in arthritis (Zakaria et al., 2009), in other studies also mention that women who are exposed to knee OA feel more severe pain and experience more pain 
lower quality of life than men (Alves and Bassitt, 2013).

\section{The effect of occupation on the quality of life of knee OA patients}

The analysis shows that there was an association between occupation and quality of life of knee OA patients. The positive association between occupation and quality of life means that knee OA patients who have rough occupation have a good quality of life 0.07 higher than knee OA patients who have fine jobs. A study by Kiadaliriet al (2016) reported that unemployed patients had greater risk to experience knee OA. This was in line with the results of this study with patient respondents who fall into the category of skilled occupation; tend to decrease activities both inside and outside the home so that it has a low quality of life. Decreased physical activity in OA patients is related to a decrease in joint value and causes poor quality of life. Groups with low physical activity / rarely moving have the poor quality of life that is seen in the measurement of physical role in SF-36 (Monteiro et al., 2011).

\section{Effect of BMI on the quality of life of knee OA patients}

There wasan association between BMI and quality of life in knee OA patients. The negative association between BMI and quality of life means that overweight/ obese knee OA patients had quality of life of 1.64 lower than knee OA patients with normal BMI.

The results of this study are in line with the study of Bindawas et al. (2018) who reported in his study that patients with high body mass index or obesity experienced severe and significant knee OA injuries to increased knee pain through the results of visual analogue scale exchange and low quality values life.

BMI has a direct association with physical fitness (Satriani et al., 2018). Exces- sive body mass index / obesity plays a role in the development of knee $\mathrm{OA}$ as the biomechanical burden of obesity can cause deviation of body weight suppression over the knee. The strength of the body load will fall medially, causing various knee responses such as changes in the pattern of the path that occurs due to the pulling of the two knees to the medial of each other, causing more severe joint damage. Therefore, weight is a major factor that requires special attention so weight loss is the best method for preventing knee OA from becoming more severe (Kasjmir et al., 2009). The risk of knee OA increases 35\% with each $5 \mathrm{~kg} / \mathrm{m}^{2}$ increase in BMI (Zheng and Chen, 2015).

\section{Effect of length of illness on the} quality of life of knee OA patients

There was an association between the duration of illness and the quality of life in patients with osteoarthritis (OA) of the knee. The negative association between duration of illness and quality of life means that knee OA patients who had chronic disease duration had a good quality of life 0.80 lower than knee OA patients who had acute illness duration.

A study by Hunter and Riordan (2014), regarding the effects of arthritis on pain and quality of life reported that respondents with a longer diagnosis of the illness experienced worse pain and various negative emotions such as feelings of frustration, fatigue, and uselessness. Most respondents reported the adverse effects of arthritis on daily activities such as lifting goods, gardening, going up and down stairs, and others.

\section{Effect of pain location on the qua- lity of life of knee OA patients}

There was an association between the location of pain and quality of life in patients with OA of the knee. The negative association between pain location and quality of 
life means that knee OA patients who have bilateral knee OA pain have a good quality of life 0.74 lower than knee OA patients who have unilateral knee OA pain locations.

Other studies mention that bilateral knee OA pain has the lowest quality of life result compared to respondents with unilateral knee pain and respondents without knee pain. These results are significant in the measurement of aspects of physical components in all variables and also significant in the measurement of aspects of mental components in sociodemmographic variables. The frequency of knee pain in adults can affect all aspects of daily activities and especially negatively affects the physical component aspects of quality of life (Bindawas et al., 2015).

Bilateral knee OA tends to develop over time because the knee joint is damaged. The knee is the largest joint in the body, there are many points of cartilage that help protect the three main bones in each leg, namely the patella, tibia, and femur (Cherney, 2017).

\section{AUTHOR CONTRIBUTION}

Wika Yuniarwati had a role in collecting data and processing study data. Achmad Arman Subijanto examined the conceptual framework and methodology of the study. Hanung Prasetyo examined the results of study and writing procedures.

\section{FUNDING AND SPONSORSHIP}

This study used independent fund

\section{CONFLICTS OF INTEREST}

There was no conflicts of interest.

\section{ACKNOWLEDGEMENT}

We thank Dr. Moewardi Hospital and UNS Teaching Hospital, Surakarta, Central Java, for giving permission to conduct the study.

\section{REFERENCE}

Alves JC, Bassitt DP (2013). Quality of life and functional capacity of elderly women with knee osteoarthritis. Einstein, 11(2): 209-215. doi: 10.1590/s1679-45082013000200013.

Bindawas SM, Vennu V, Al Snih S (2015). Differences in health-related quality of life among subjects with frequent bilateral or unilateral knee pain: data from the osteoarthritis initiative study. J Orthop Sports Phys Ther, 45(2): 128-136. doi: 10.2519/jospt.2015.5123.

Bindawas SM, Vennu V, Alfhadel S, AlOtaibi AD, Binnasser S (2018). Knee pain and health-related quality of life among older patients with different knee osteoarthritis severity in Saudi Arabia.PLOS ONE, 13(5): 1-9. doi: /doi.org/10.1371.

BPS (2017). Angka harapan hidup tahun 2017. Retrieved from: www.bps.go.id.

CDC (2018). Health related quality of life (HRQOL) concept. Retrieved from: www.cdc.gov.

Depkes (2018). Peningkatan penduduk lanjut usia. Retrieved from: www.depkes.go.id.

Ermawati DH, Budihastuti UR, Murti B (2018). Menopause and biopsychosocial factors associated with quality of life in women in Surakarta, Central Java. J Matern Child Health, 3(2): 119-127. doi: doi.org/10.26911.

Hafizh M, Tanti A (2015). Gambaran kualitas hidup dan tingkat kecemasan pasien osteoartritis lutut di instalasi rehabilitasi medik RSUP Dr. Kariadi Semarang.Media Medika Muda, 4(4): 1252-1260. https://ejournal3.undip.ac.id.

Hunter DJ, Riordan EA (2014). The impact of arthritis on pain and quality of life: 
an australian survey study design. Int J Rheum Dis, 17(2): 149-155. doi: /doi.org/10.1111.

Ismail A, Sari IP, Pramantara IDP (2013). Evaluasi kualitas hidup pada pasien osteoartritis di instalasi rawat jalan rumah sakit periode februari - mei 2013. Jurnal Manajemen dan Pelayanan Farmasi, 3(4): 223-230. https://jurnal.ugm.ac.id.

Kasjmir YI, Nasution AR, Daud R (2009). Risk factors for the development of knee osteoarthritis. J Rheumatol, 1(1): 19-25. https://journalrheumatology.or.id.

Kiadaliri AA, Lam CJ, De Verdier MG, Engstrom G, Turkiewicz A, Lohmander LS, Englund M (2016). Association of knee pain and different definitions of knee osteoarthritis with health-related quality of life: a population-based cohort study in Southern Sweden. Health Qual Life Outcomes, 14(1): 1-7. doi: 10.1186/s12955-0160525-4.

Kusumaningtyas M, Tamtomo D, Murti B (2019). Factors associated with the occurrence of osteoarthritis: a path analysis evidence from Surakarta, Central Java. Epidemiology and $\mathrm{Pu}-$ blic Health, 4(1): 9-19. doi: /doi.org/10.2691.

Lowry V, Ouellet P, Vendittoli PA, Carlesso LC, Wideman TH, Desmeules F (2017). Determinants of pain, disability, health-related quality of life and physical performance in patients with knee osteoarthritis awaiting total joint arthroplasty. Disability and Rehabilitation, 1-11. Doi: 10.1080/09638288.2017.1355412.

Maharani (2007). Faktor-faktor risiko osteoartritis lutut. TESIS, Semarang: Universitas Diponegoro.

Monteiro E, Neto DF, Queluz TT (2011). Physical activity and its association with quality of life in patients with osteoarthritis. Rev Bras Reumatol, 51(6): 539-544.

Satriani HA, Indarto D, Dewi YLR (2018). The path analysis of body mass index, physical exercise, sleep quality, and parental education on physical fitness among male adolescences.Journal of Health Promotion and Behavior, 3(4): 270-278. doi: /doi.org/10.26911.

Sazlina, SG, Zaiton A, Nor Afiah MZ, Hayati KS (2012). Predictors of health related quality of life in older people with non-communicable diseases attending three primary care clinics in Malaysia. J Nutr Health Aging, 16(5): 498-502. doi: 10.1007/s12603-0120038-8.

Zakaria ZF, Bakar AA, Hasmoni HM, Rani FA, Kadir SA (2009). Health-related quality of life in patients with knee osteoarthritis attending two primary care clinics in Malaysia: a cross-sectional study. BioMed Central, 8(10): 1-7. doi: 10.1186/1447-056X-8-10.

Zheng H, Chen C (2015). Body mass index and risk of knee osteoarthritis: systematic review and meta-analysis of prospective studies.BMJ Open, 5(12). doi: 10.1136/bmjopen-2014-007568. 